\title{
Late Holocene Paleoseismicity of the Southern Part of the Chelungpu Fault in Central Taiwan: Evidence from the Chushan Excavation Site
}

\author{
by Wen-Shan Chen, Chih-Cheng Yang, I-Chin Yen, Long-Sheng Lee, Kun-Jie Lee, \\ Hsiao-Chin Yang, Hui-Cheng Chang, Yoko Ota, Chii-Wen Lin, Wei-Hsiung Lin, \\ Tung-Sheng Shih, and Shih-Ting Lu
}

\begin{abstract}
The geomorphic expression of the frontal Western Foothills in central Taiwan is usually defined by a late Holocene scarp that ranges from tens to hundreds of meters in height. This scarp is the product of displacement on a near-surface 20$30^{\circ}$ east-dipping thrust fault, the Chelungpu fault, which ruptured during the Chichi earthquake. The large scarp height may correspond directly to the accumulation of successive surface ruptures. The Chushan site is located on the southern part of this fault where the Chichi earthquake produced a scarp with a $1.7-\mathrm{m}$ vertical offset for the total vertical separation. Based on core-boring estimates, the vertical displacement on both sides is $7 \mathrm{~m}$ along a $24^{\circ}$ east-dipping thrust fault. The results from our paleoseismic analysis indicate that five large paleoearthquake events have caused the large offsets during the past $2 \mathrm{ka}$. The radiocarbon age constraints of the paleoearthquakes suggest a clustering of 540-790 cal yr B.P. (E2), 710-950 cal yr B.P. (E3), 1380-1700 cal yr B.P. (E4), 1710-1930 cal yr B.P. (E5), and the 1999 Chichi earthquake. Events E3 and E4 have not been reported in previous studies and we did not observe event E1 (300-430 cal yr B.P.) at the site. Based on displacement and fault segmentation from the geologic features, we argue that the two new events may have occurred along the northern part of the Chelungpu fault. The vertical slip rate is estimated to be at least $3.9 \pm 0.2 \mathrm{~mm} / \mathrm{yr}$ over the past $2 \mathrm{ka}$, which is similar to the long-term estimation through a calculation of late Pleistocene-Holocene terrace elevations on the hanging wall.
\end{abstract}

\section{Introduction}

The 1999 Chichi earthquake $\left(M_{\mathrm{w}} 7.6\right)$ was one of the most damaging earthquakes in the world during the past ten years. The epicenter was located at $23.87^{\circ} \mathrm{N} / 120.75^{\circ} \mathrm{E}$ with a focal depth of about $10 \mathrm{~km}$, and the fault-plane solutions of the mainshock define a N $3^{\circ} \mathrm{W}$-striking fault, dipping $30^{\circ} \mathrm{E}$ (Shin et al., 2000). The earthquake was caused by thrust faulting that produced a visible surface rupture of $95 \mathrm{~km}$ along the front of the Western Foothills (Fig. 1; Chang, 1999; W. S. Chen et al., 2001c; Y. G. Chen et al., 2001). This active fault separates Pliocene and Holocene deposits, and has produced easily identifiable and prominent geomorphic features in the past $0.5-0.7 \mathrm{Ma}$ (W. S. Chen et al., 2001c). Since the Chichi earthquake, several studies have attempted to characterize the geomorphic expression of the fault in Holocene terrace and fluvial deposits (Sung et al., 2000; W. S. Chen et al., 2003; Y. G. Chen et al., 2002, 2003; Ota et al., 2005, 2006).

The Chichi earthquake rupture shows complex structural and stratigraphic relationships that can be divided into three segments: the Shihkang, Chelungpu, and Tajianshan faults (Fig. 1; W. S. Chen et al., 2001c, 2003). The Shihkang fault to the north is a bedding-slip thrust in the near surface within Pliocene shale. The fault plane remains in Pliocene shale to depths of $1.1 \mathrm{~km}$, based on extrapolation from the Taiwan Core Drilling Project deep borehole (Fig. 1). The Chelungpu fault in the middle segment carries Pliocene shale in the hanging wall and a thick sequence of Quaternary deposits in the footwall. The Tajianshan fault to the south has lower Pliocene sandstone-shale in the hanging wall and Pleistocene sandstone-conglomerate in the footwall. This is bounded by the Luliao fault, a strike-slip fault that is further to the south.

Seismic data and geologic field measurements show that the coseismic deformation is clearly partitioned by the different structural domains that are defined by the three fault segments. The Shihkang fault defines a $\mathrm{N} 30-40^{\circ} \mathrm{W}$-verging oblique thrust system with vertical displacements that range from 3 to $9.5 \mathrm{~m}$, whereas the Chelungpu fault defines a N70 $90^{\circ} \mathrm{W}$-verging pure thrust fault with vertical displacements that range from 0.5 to $3 \mathrm{~m}$. The Tajianshan fault, in contrast, 


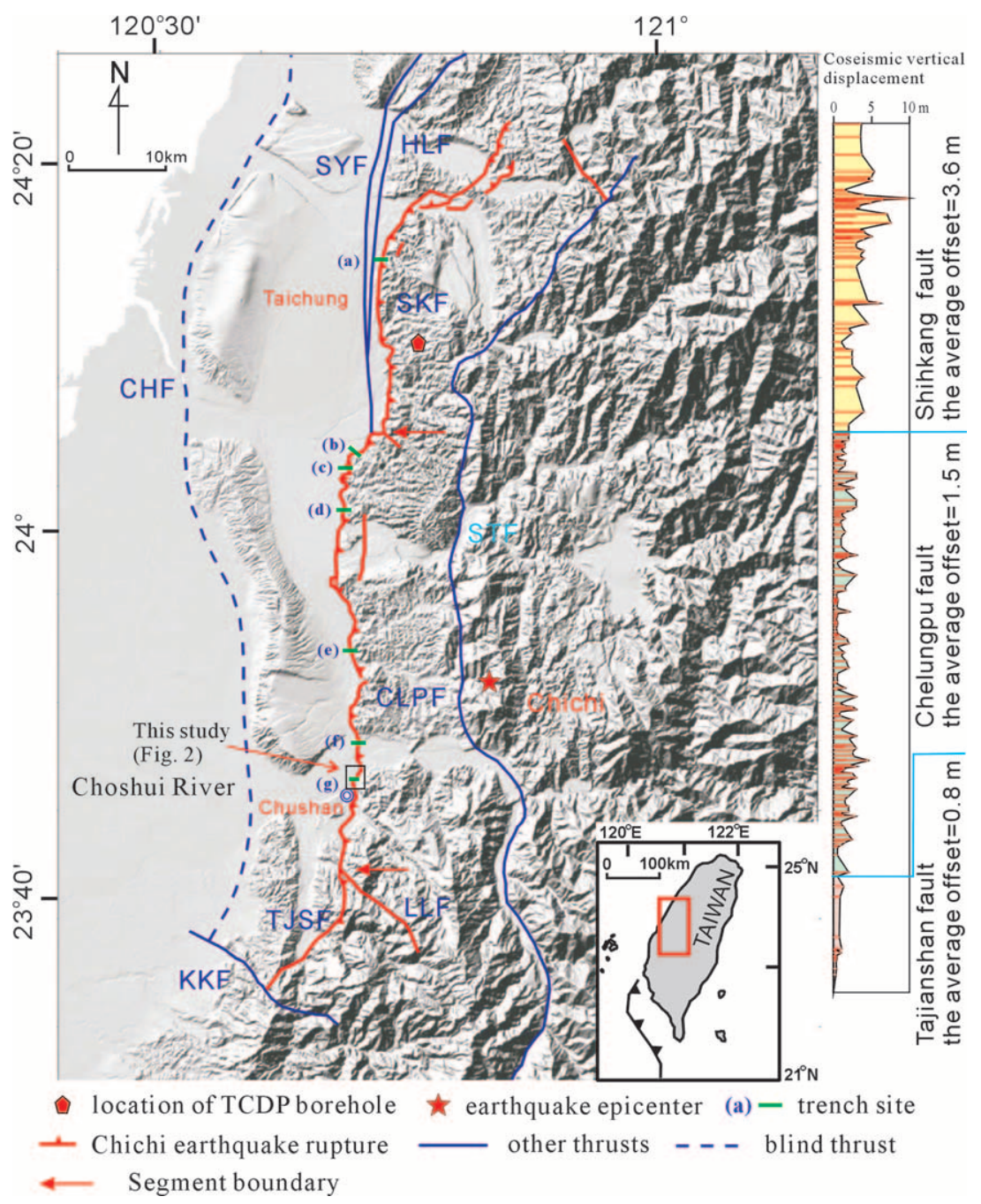

Figure 1. Geomorphological map of central Taiwan and locations of the trench sites (ag). The Chichi earthquake rupture was along the frontal Western Foothills, and is subdivided into the Shihkang, Chelungpu, and Tajianshan faults. CHF, Changhua fault; CLPF, Chelungpu fault; HLF, Houli fault; SKF, Shihkang fault; STF, Shuangtung fault; SYF, Sanyi fault; TJSF, Tajianshan fault; LLF, Luliao fault; KKF, Kukeng fault; (a) the Fengyuan site (Ota et al., 2005, 2006); (b) the Pineapple field site (W. S. Chen et al., 2004); (c) the Siangong temple site (W. S. Chen et al., 2006); (d) the Wanfung site (W. S. Chen et al., 2001b); (e) the Shijia site (W. S. Chen et al., 2006; A. R. Streig et al., unpublished manuscript, 2006); (f) the Mingjian site (W. S. Chen et al., 2001a); and (g) the Chushan site (this study). has a slip vector that is oriented $\mathrm{N} 50^{\circ} \mathrm{E}$ and vertical displacements which range from 0.2 to $1 \mathrm{~m}$ (W. S. Chen et al., 2001c).

The Chichi earthquake was one of the largest earthquake events documented in central Taiwan during the past three centuries (Hsieh and Tsai, 1985). The area contains many known active faults, such as the Changhua, Houli, and Chelungpu faults, which have displaced the late PleistoceneHolocene deposits (W. S. Chen et al., 2001c). Before the Chichi earthquake, the Chelungpu fault was not classified as an active fault in the Taiwan seismic catalogs, because there was no direct evidence of surface rupture. Hence, no detailed studies were completed on it. However, extensive paleoseismological research has been performed since the Chichi earthquake to better document the paleoseismic history. To delineate the timing and recurrence intervals of the Chelungpu fault, we excavated seven trenches across it, and these contained evidence of four surface-rupturing earthquake events during the past $2 \mathrm{ka}$, including the Chichi earthquake (W. S. Chen et al., 2001a, b, 2004, 2006; Ota et al., 2001, 2005, 2006; A. R. Streig et al., unpublished manuscript, 2006). In this article, we integrate data from a recent trench near Chushan with previous paleoseismological results along the Chelungpu fault, and discuss their implications for the late Holocene paleoseismicity history of the fault.

\section{Stratigraphy}

The Chushan site is located on a 3-m-high river terrace; the Chichi earthquake rupture was located between this terrace and the Western Foothills (Fig. 2). We excavated an approximately southeast-trending, 35-m-long, 14-m-wide, and 8-m-deep trench that exposed two depositional sequences (Figs. 3-6). These two sequences represent an abrupt change in the local depositional environment from fluvial to alluvial environments. The lower sequence comprises channel deposits of thick-bedded boulder conglomerate that were deposited from the Choshui River. The upper sequence records colluvial and alluvial sedimentation by slope wash and a tributary stream. We identified seven depositional units within these two sequences based on their distinctive lithologies.

The basal unit of the fluvial sequence represents braided-river deposits from the Choshui River, and is com- 


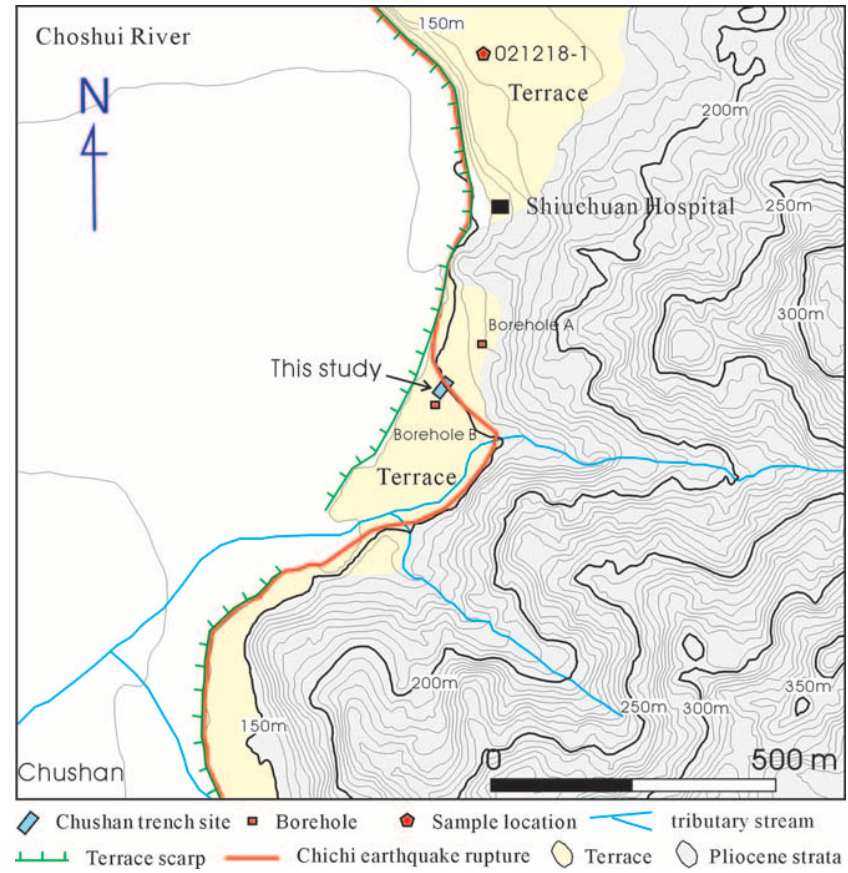

Figure 2. Microtopographic map of the trench site. The map shows the location of the Chushan trench and the Chichi earthquake rupture. The contour line interval is $5 \mathrm{~m}$. The location is shown in Figure 1.

posed mainly of quartzite boulders that derive from the Central Range (unit G; Figs. 4 and 6). One wood sample that was collected from fluvial terrace deposits near the trench site and interpreted to be correlative with unit $\mathrm{G}$ yielded a radiocarbon age of 3473-3820 cal yr B.P. (sample 021218-1; Fig. 2). Based on borehole $B$, unit $G$ occurs at $8.2 \mathrm{~m}$ in the footwall and is $8 \mathrm{~m}$ thick. A corresponding fluvial boulder bed in the trench has a 7-m vertical separation across the main fault (Figs. 2 and 7).

The upper sequence is divided into six units, which include in ascending order a massive sand layer with lenticular gravel beds (unit F), mud with a thin sand layer (unit E), silt with a thin mud layer (unit D), silty mud (unit C), silt that is interbedded with organic-rich layers (unit B), and sand with lenticular gravel beds (unit A) (Figs. 3-6). Unit F comprises angular sandstone and shale clasts, and appears to be derived from a tributary stream that is located east of the site where the late Pliocene strata are exposed (Fig. 2). The change in the depositional environment at the site was probably caused by the migration of the Choshui River channel away from the site. Hence, unit F marks the initiation of an alluvial-fan deposition at the site that is defined by sandy material derived locally via the tributary stream. The radiocarbon dates of two samples from unit $\mathrm{F}$ yielded ages of 2980-3250 cal yr B.P. (Zs067) and 3210-3375 cal yr B.P. (Zs044), thus indicating that the alluvium was deposited about 2980-3375 cal yr B.P. (Figs. 3, 4, and 8).

Sedimentary structures such as laminations and lenses of very fine sand suggest that well-stratified units E, D, C, and $\mathrm{B}$ were deposited on the hanging wall by the flooding of a tributary stream from the Western Foothills. The thin, poorly sorted, clast-supported lenticular gravel beds comprising sandstone clasts could be interpreted as channel deposits that formed during heavy rain and storms. Two detrital charcoal samples were analyzed from units $\mathrm{E}$ and $\mathrm{C}$, yielding ages of 3155-3360 cal yr B.P. (Zs163) and 2740-2790 cal yr B.P. (Zs119), respectively (Figs. 3, 4, and 8). A detrital charcoal sample that was collected from unit D yielded a radiocarbon age of 3440-3620 cal yr B.P. (Zs172), which is older than the deposition ages of units $\mathrm{E}$ and $\mathrm{F}$. This indicates that the sample was probably reworked from unit $\mathrm{G}$ (Fig. 8).

The alluvial sequence of unit B contains four thin layers of well-sorted silt that are interbedded with organic-rich layers (B1-B4) that have been slightly modified by pedogenic processes. We interpret these well-sorted and laminated silt beds as being the result of fine sediment settling after flooding. The organic-rich layers display onlapping relationships, in which younger layers pinch out over older layers. For example, the B3 layer onlaps the B4 layer and the B1 layer onlaps the B3 layer (Figs. 3 and 4). These relations suggest that the B1-B4 layers were deposited in the footwall and onlapped the scarp. In addition, the B2 and B 3 layers display convoluted layer, clastic dike, and crack-filling features that are probably the result of earthquake-induced liquefaction (Obermeier and Pond, 1999).

Detrital charcoal that was collected from the B4 layer yielded radiocarbon ages of 1740-1930 cal yr B.P. and 1990-2320 cal yr B.P., thus indicating a depositional age of 1740-2320 cal yr B.P. (Zs128, Zs126; Figs. 3, 4, and 8). The B3 layer contains abundant detrital charcoal. The radiocarbon ages that were taken from this unit of 1700-1870 cal yr B.P. (Zs132), 1500-1690 cal yr B.P. (Zs136), 1540-1720 cal yr B.P. (Zs111, Zs102), 1530-1710 cal yr B.P. (Zs082), and 1420-1600 cal yr B.P. (Zs109) on the north wall, and 16201840 cal yr B.P. (Zs096) and 1405-1565 cal yr B.P. (Zs201) on the south wall. The timing of the B2 and B3 layers are well constrained by additional radiocarbon dates. We suggest that the depositional age can be inferred to be the intersection age. The overlaps on these dates suggest that the B3 layer was formed approximately 1540-1710 cal yr B.P. (Fig. 8). Four detrital charcoal samples that were collected from the B2 layer yielded radiocarbon dates of 1540-1720 cal yr B.P. (Zs131) and 1520-1700 cal yr B.P. (Zs117) on the north wall, and 1540-1810 cal yr B.P. (Zs310) and 1550-1740 cal yr B.P. (Zs312) on the south wall. These dates overlap within the range of 1550-1700 cal yr B.P., which means that the B3 and B2 layers were deposited during roughly the same interval. The B1 layer yielded radiocarbon dates that ranged from 780-950 cal yr B.P. (Zs100) to 710-920 cal yr B.P. (Zs503), whereas the silt overlaying the B2 layer dated at 1380-1550 cal yr B.P. (Zs135) (Figs. 3, 4, and 8). Samples Zs100 and Zs503 were collected from the organic-rich layer to represent the deposition age of the top B1 layer, and sample Zs135 was collected from a silt bed on the north wall 


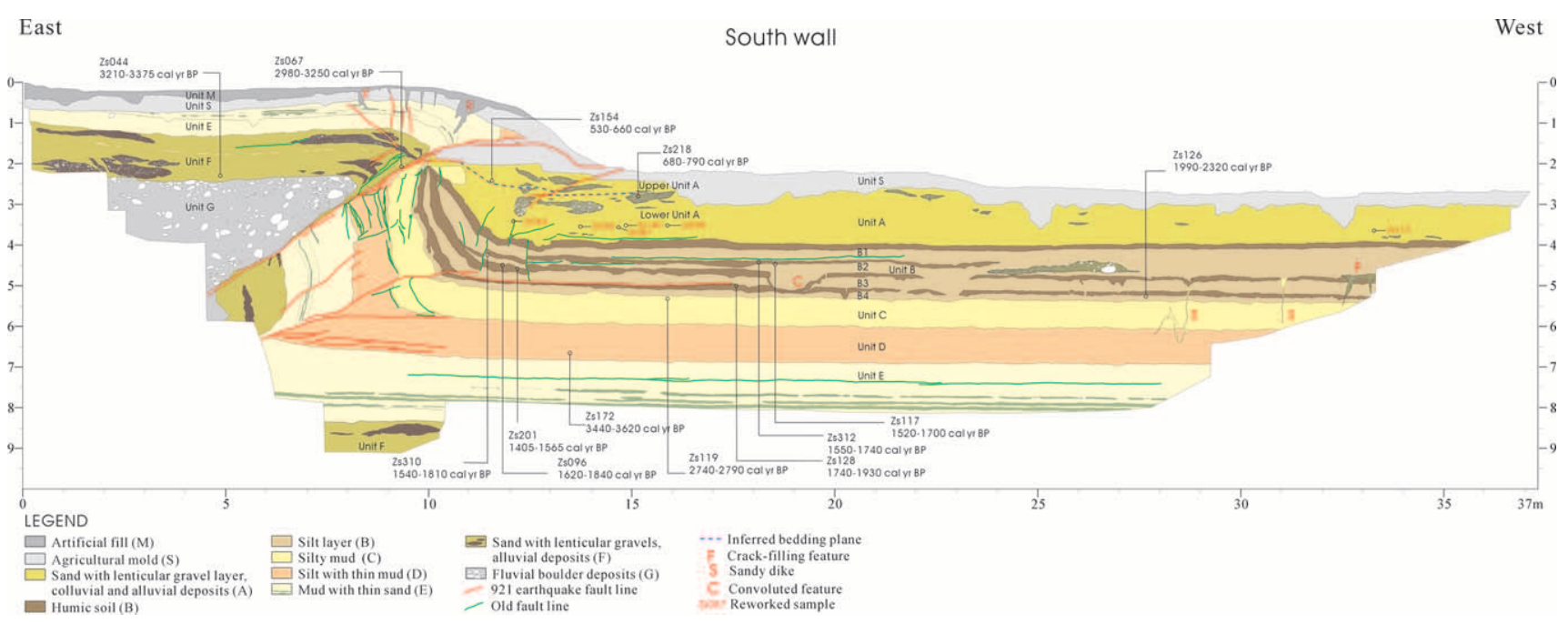

Figure 3. $\quad$ Log of the south wall, showing calendric ages of ${ }^{14} \mathrm{C}$ samples. The locations of charcoal are indicated by open circles. The red lines are the Chichi earthquake fault strands. Paleoearthquake fault strands are shown by the green lines.

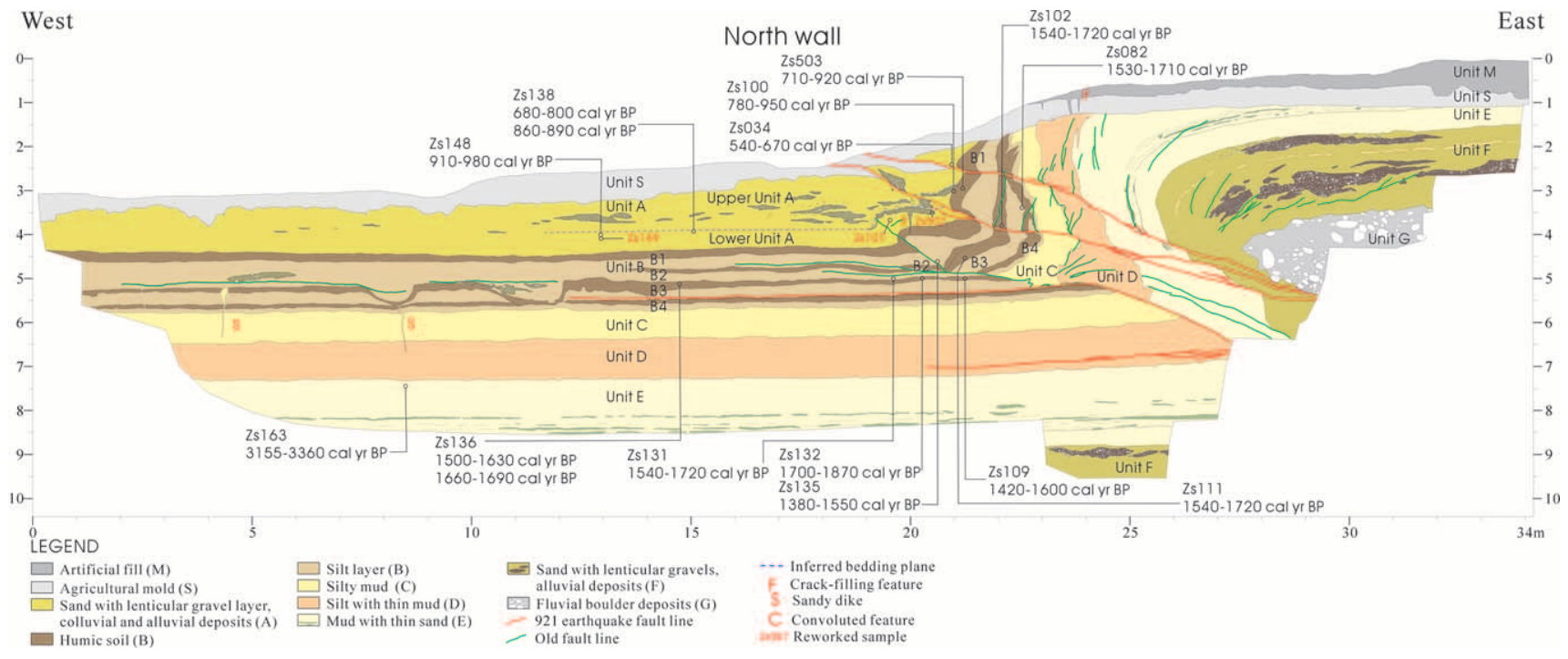

Figure 4. Log of the north wall, showing calendric ages of ${ }^{14} \mathrm{C}$ samples. The locations of charcoal are indicated by open circles. Red lines label the Chichi earthquake faults. Green lines label the paleoearthquake faults.

to represent the earlier deposition age. Collectively, these dates suggest that the depositional age of the B1 layer is $710-1550$ cal yr B.P.

Unit A comprises sand with a lenticular sandstone gravel layer that was deposited by washout and tributary stream processes in the hanging wall. These strata unconformably onlap the B1 layer (Figs. 3 and 4). Unit A can be divided into two subunits: a lower unit $\mathrm{A}$, which contains deformation features that are related to folding and shearing, and upper unit $\mathrm{A}$, which overlays lower unit $\mathrm{A}$. Because of the lack of correlative deposits, it is difficult to clearly define the unconformable surface. Lower unit A yielded calibrated dates of 910-980 cal yr B.P. (Zs148), 680-890 cal yr B.P.
(Zs138), and 680-790 cal yr B.P. (Zs218), thus indicating a depositional age of around 680-980 cal yr B.P. Upper unit A yielded calibrated dates of 540-670 cal yr B.P. (Zs034) and 530-660 cal yr B.P. (Zs154), thus indicating a depositional age of between 530 and $670 \mathrm{cal}$ yr B.P. (Fig. 8). The timing of the depositions of the B1 layer, lower unit $\mathrm{A}$, and upper unit $\mathrm{A}$ is poorly constrained by few radiocarbon dates, which suggests that the depositional age is the union age. In addition, lower unit $\mathrm{A}$ contains numerous reworked charcoals, the ages of which are greater than at the top of the B1 layer and similar to those of the B2 and B3 layers (Fig. 8). We also found some organic-rich mud chips (unit B) within lower unit $\mathrm{A}$. These relationships suggest that lower unit $\mathrm{A}$ 


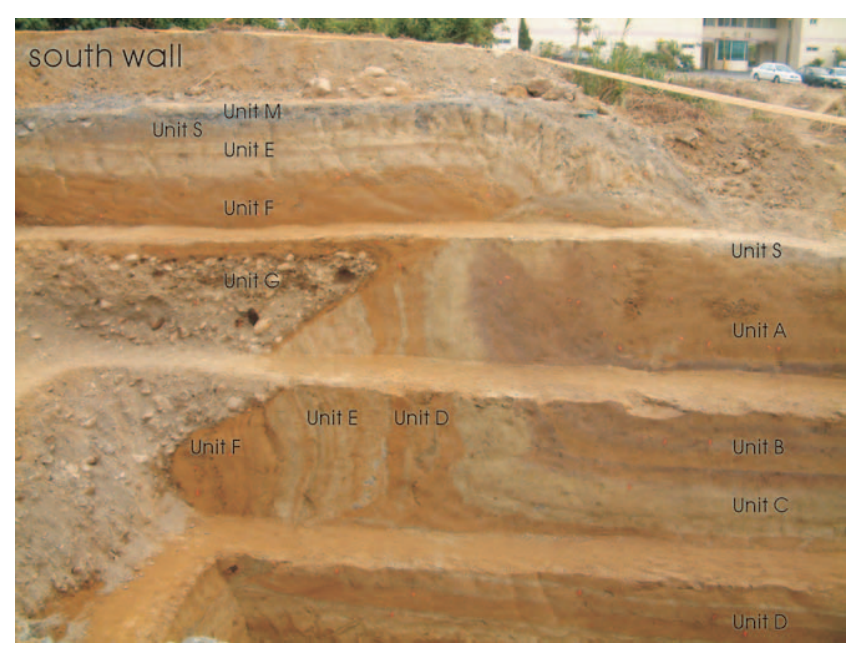

Figure 5. Photo of the south wall showing a $32^{\circ}$ east-dipping main thrust and the fault scarp that was formed by the Chichi earthquake. The hanging-wall structure is a broadly open anticline, and the footwall is characterized by a syncline with the axial surface approximately parallel to the thrust.

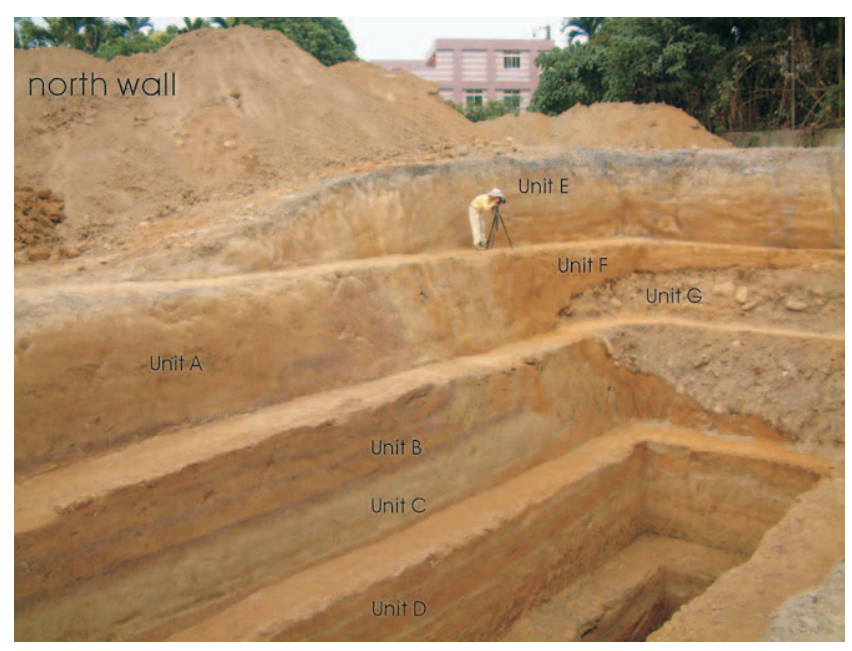

Figure 6. Photo of the north wall showing a tight anticline with a steeply inclined (overturned) forelimb on the hanging wall.

reworked the unit B detritus that was eroded from the hanging wall. Based on the radiocarbon dates and composition, we interpret the colluvial deposits of unit $\mathrm{A}$ as being derived from unit B, which is located on the nearby hanging wall. Unit $S$ on the top surface has been modified by agricultural activity to depths of 0.4-2 $\mathrm{m}$ and covers the fault zone. Unit M on the surface of the hanging wall is overlaid by unit $\mathrm{S}$ and comprises human-modified gravel that is used for a building foundation.

\section{Structural Characteristics}

Within the Chushan trench, there are several good examples of Chichi earthquake ruptures across which linear artificial features can be measured for vertical and horizontal displacements. The rupture along this scarp shows a 1- to 3-m-high vertical offset and displays east-to-west-directed shortening with a pure thrust displacement (Chang, 1999; W. S. Chen et al., 2001a, b; Kelson et al., 2001; Lee et al., 2001).

Previous trenches along the Chichi earthquake rupture have shown that fault-tip deformation can be subdivided into breakthrough thrust and blind-thrust components (W. S. Chen et al., 2001a, b, 2004, 2006; Ota et al., 2001; A. R. Streig et al., unpublished manuscript, 2006). The occurrence of surface coseismic deformation can be identified by relationships between the structural and sedimentological features, such as colluvial wedges, angular unconformities, and onlap geometries. We will exploit these types of relationships to characterize the surface deformation that is associated with the sedimentary features of the Chushan site.

\section{The 1999 Chichi Earthquake Deformation}

Unit S on the top surface allowed us to directly observe the deformation that occurred during the Chichi earthquake. Based on the deformation of unit $\mathrm{S}$, the earthquake appears to have ruptured the ground surface with sufficient displacement to transport the hanging wall over it, producing a convex west-facing scarp (Figs. 3, 4, and 9a,b). By restoredeformating unit $\mathrm{S}$, we can show that the Chichi earthquake produced $1.7 \mathrm{~m}$ of vertical displacement and about $3.5 \mathrm{~m}$ of horizontal shortening on an east-dipping near-surface fault that is oriented $32^{\circ}$ in the south wall and $20-24^{\circ}$ in the north wall (Fig. 10a,b). Continuously cored borings that were drilled to a depth of $60 \mathrm{~m}$ on the hanging wall and to $50 \mathrm{~m}$ on the footwall revealed further subsurface constraints (Fig. 7). Borehole A, which was drilled on the hanging wall, showed the location of the fault zone at a depth of $54.3 \mathrm{~m}$, where Pliocene shale is displaced over sand deposits. This relationship suggests a fault dip of $24^{\circ}$ which is consistent with the measurement of the fault plane in the trench. The lithologic characteristics of borehole B in the footwall also reveal two depositional sequences of fluvial and alluvial/ colluvial deposits that corresponded with the excavated profile.

Fault-tip deformation in the south wall of the Chushan trench is exposed as a fault-bend fold with an asymmetric fold and a ramp-flat thrust (Figs. 3, 5, and 9a). A hangingwall anticline and footwall syncline have also developed along the fault. The hanging-wall anticline contains two oppositely dipping thrust faults: a main east-dipping thrust and a minor west-dipping backthrust (Fig. 9a). A horizontal thrust at the leading edge of the fault tip bulldozed into the footwall ground surface. Here, the lower unit of alluvial deposits (units D and E; Fig. 9a) is faulted against the uppermost unit of artificial fill (unit M). Along the crest of the hanging-wall anticline are several wedge-shaped ground cracks, normal faults, and a backthrust (Fig. 3). We interpret these structures as being produced by a flattening of the 


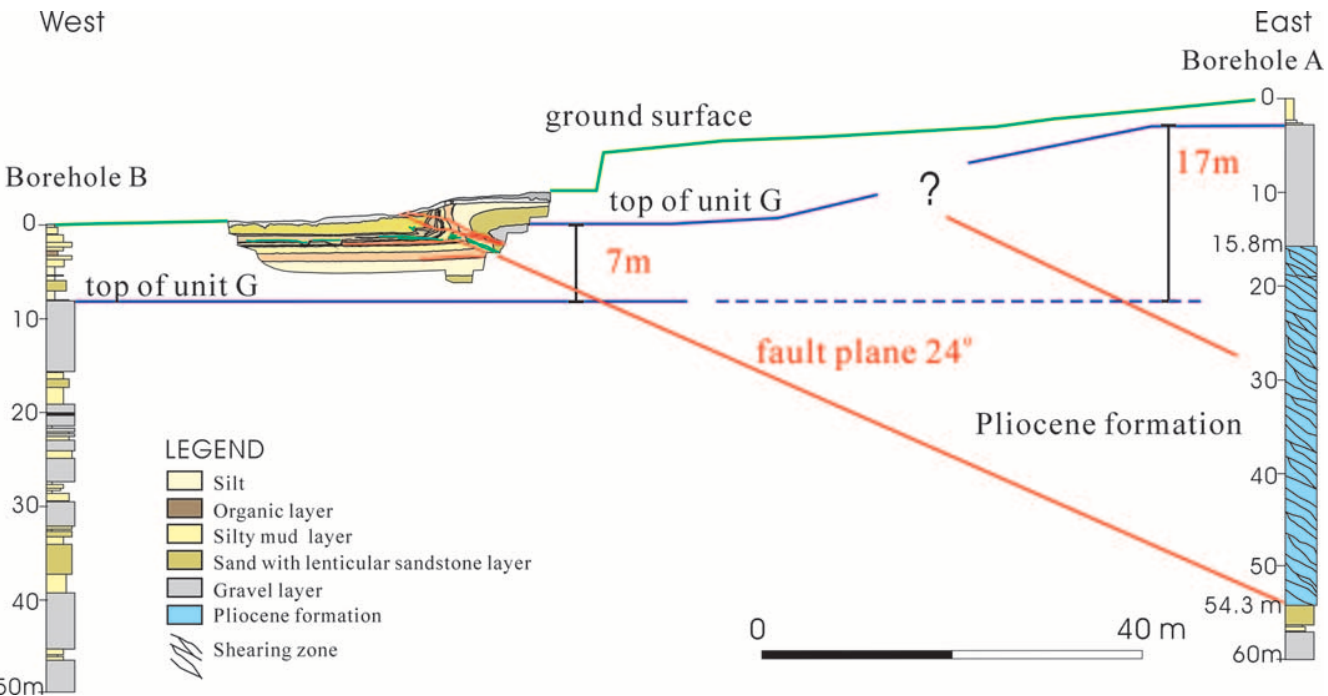

Figure 7. The well log of borehole A on the hanging wall reveals a fault zone at $54.5 \mathrm{~m}$ depth. Correlation with the shear zone between borehole A and the fault tip on the surface identifies $24^{\circ}$ fault-plane dipping. Unit $\mathrm{G}$ of gravel deposits between borehole $\mathrm{B}$ and the trench profile on the hanging wall is offset $7 \mathrm{~m}$ high on both sides of the fold scarp.

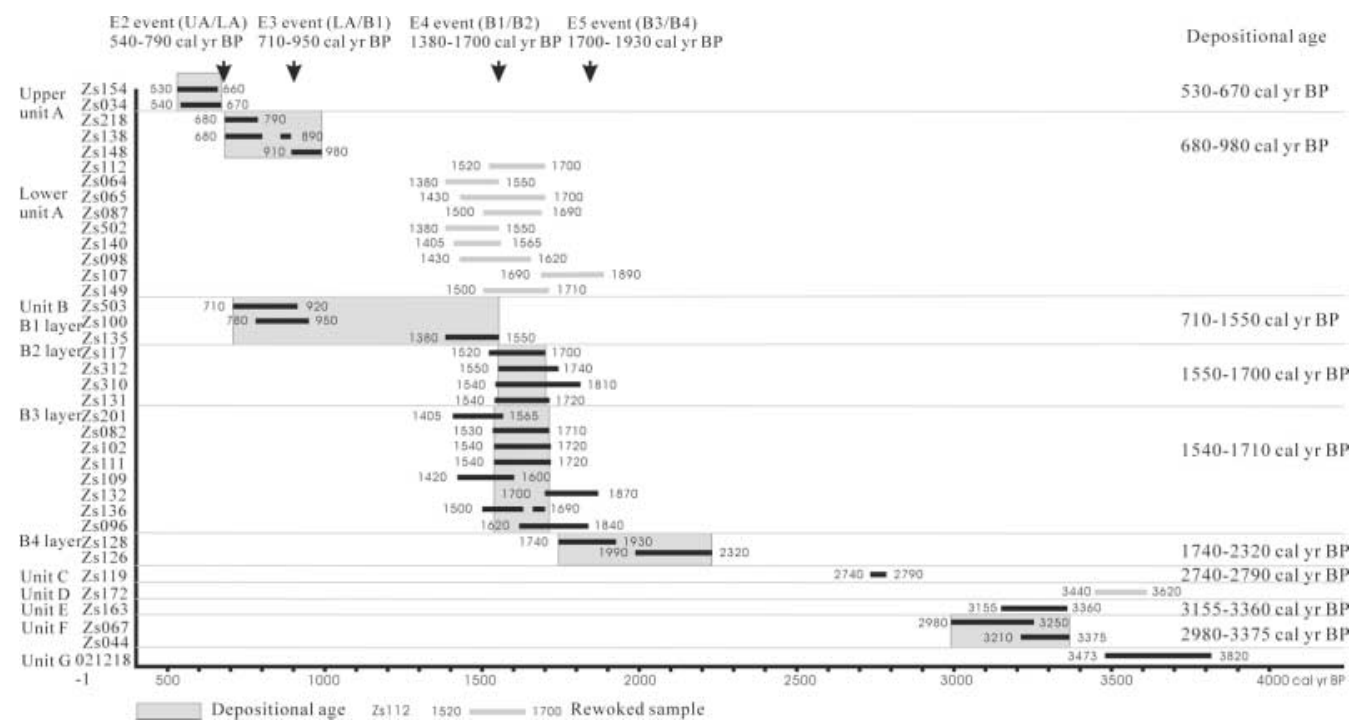

Figure 8. Chronological constraints of the inferred paleoearthquake events and the deposition of stratigraphic units. The timing of the B2 and B3 layers are well constrained by more radiocarbon dates, which suggests that the depositional age is used as the intersection age. The other units are poorly constrained by few radiocarbon dates and by using the union age.

thrust fault from a ramp to a flat, thus producing localized tension along the fold hinge. In addition, numerous sheared planes, which are related to the Chichi earthquake and located within the footwall synclinal forelimb, are distinctive in that they cut the pre-existing sheared planes, weatheredmottle structures, and several layer-parallel slip faults. Footwall folding has produced a thinning and oversteepened synclinal forelimb due to the shearing and dragging that has been associated with the repeated paleoearthquakes.
On the north wall of the trench, the folding style is more akin to a fault-propagation fold. Associated with the Chichi earthquake, the thrust ramp exhibits a 2-m-wide ductile shear zone that comprises two main thrusts and two minor beddingslip faults in which the ramp thrust dips $20-24^{\circ}$ toward the east (Fig. 9b). Detailed measurements of the displacement using marked beds and the ground surface on both sides of the fault zone showed that the total displacement for the two thrusts is about $1.8 \mathrm{~m}$ vertical and $3.2 \mathrm{~m}$ horizontal. 


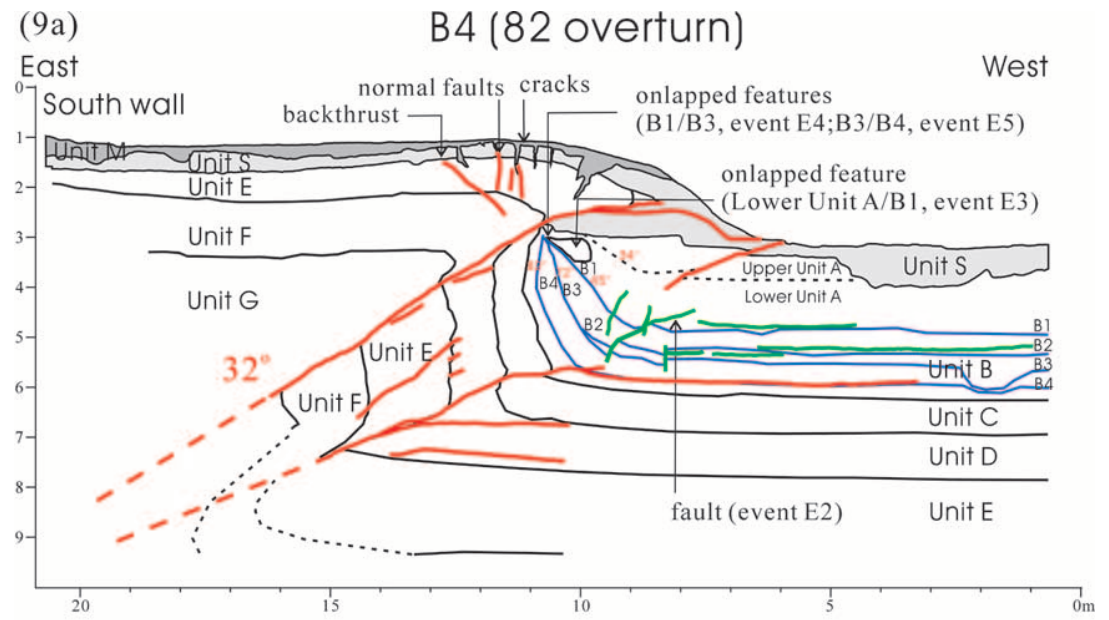

Figure 9. Sketches of the structural and stratigraphic features of the earthquake rupture on the south wall (a) and north wall (b). The red lines show the Chichi earthquake fault strands, and the red dashed lines are the inferred Chichi earthquake fault strands. The green lines show the paleoearthquake fault strands. The black lines show the bedding plane. The blue lines show the unit B bedding plane. The black dotted lines show the inferred bedding plane.

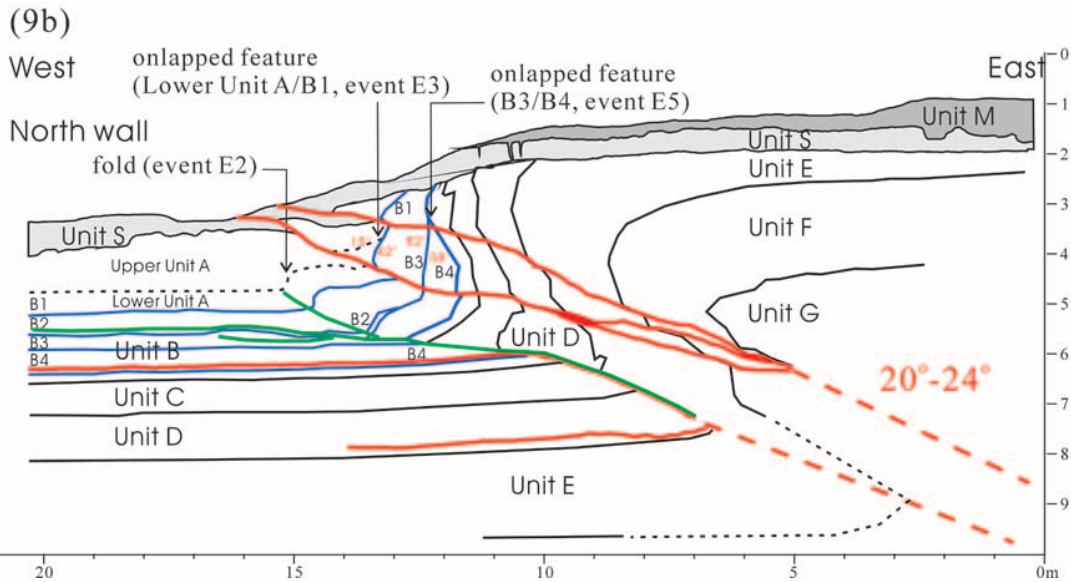

The horizontal offset in the north wall is less than that found in the south wall, which suggests that part of the horizontal shortening may be absorbed by bed thinning (units C, D, E, and $\mathrm{F}$ ) and progressive anticline forelimb rotation toward the footwall. A ductile shear zone near the ramp thrust commonly forms rollover folds that display heterogeneous deformational features such as bed thinning in the overturned forelimb on the hanging wall (e.g., Storti et al., 1997).

\section{The Pre-1999 Chichi Earthquake Deformation}

After restoring the deformation that was created by the Chichi earthquake, the folding geometry displays a ramp thrust on the frontal upthrown block. The fold shows different geometries on each side of the trench wall (Fig. 10a, b). The structural geometry of the south wall shows an eastdipping $32^{\circ}$ breakthrough thrust along the anticlinal axial plane that produces an open anticline on the hanging wall (Fig. 9b). The hanging wall structure has a broad flat backlimb and a narrow shear zone concentrated within a $0.2-\mathrm{m}-$ wide zone that is adjacent to the major fault plane. The footwall is characterized by a syncline with the axial plane approximately parallel to the thrust. The synclinal forelimb below the thrust is defined by a 2-m-wide deformation zone with numerous locally developed thin shear planes. The un- folded strata on the hanging wall suggest that the fault tip broke through the ground surface at an earlier stage (event E3), even as the fault continued to propagate and the footwall continued to fold (Fig. 10c). Hence, additional shortening was accommodated in the hanging wall by direct displacement on the main thrust, which produced more "runout" where the hanging wall overrides the footwall. This phenomenon produced less folding deformation in the hanging wall but contributed to less coherence, which suggests a hanging-wall-fixed fault-propagation folding mechanism (e.g., Erslev, 1991).

The north wall contains a tight anticline with a steeply inclined forelimb on the hanging wall (Fig. 4). The exposure exhibits a rounded and recumbent fold geometry (Fig. 10a,b) in which progressive tilting of the unfaulted strata on the hanging wall occurred during the earlier stage (Fig. 10c,d). Our measurements show progressively steeper dips of the hanging wall in the vicinity of the fault, local thickening of the strata in the anticlinal hinge, and thinning of the beds on the forelimb. The forelimb is dominated by flexural slip within the deformation zone due to fold-forward rotation. We interpret the deformation within the forelimb area as being the product of hanging-wall strata rolling into the deformation zone as the folding grew numerous layer-parallel slipshear planes. Hence, the bedding slip indicates that the 


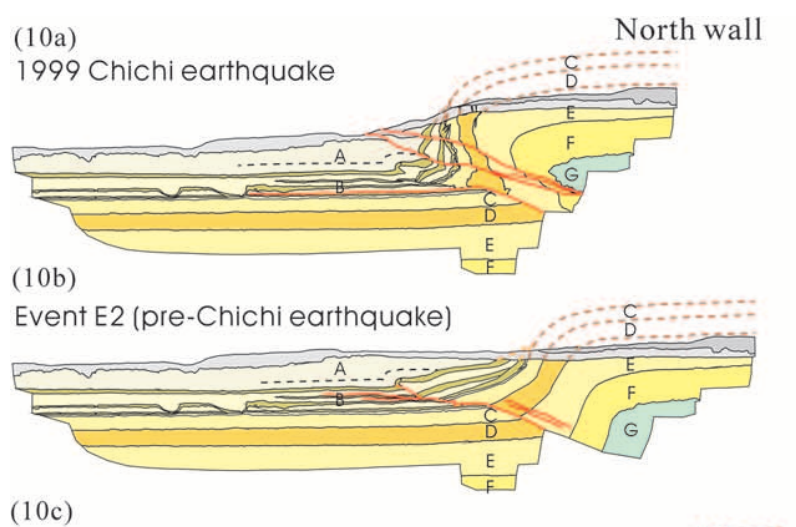

South wall
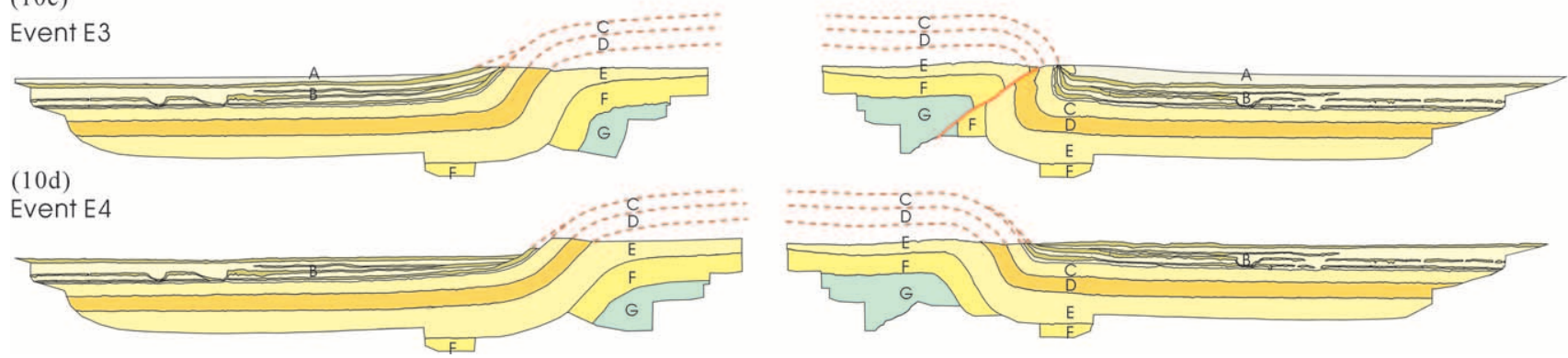

Figure 10. Explanation of the restored deformed-logs of the north and south walls. The restoration shows progressive unstripping of stratigraphy and removal of deformation from the Chichi earthquake event to event E3. The red lines label the coseismic rupture of each event.

overall deformations may have been quite large, in particular, in the forelimb. Less displacement occurred on the main thrust faults, with more shortening accommodated by hanging-wall folding. The footwall strata are unfolded, so that the folding seems to be fixed to the footwall. Based on the fold geometry, we propose that this deformation represents a fault-propagation fold related to blind thrusting during the initial stage of the deformation (Fig. 10c,d).

\section{Paleoseismological Analysis}

The total vertical offset at the top of the oldest unit (unit $\mathrm{G}$ ) is estimated at $7 \mathrm{~m}$, based on exposures in the Chushan trench and a nearly core hole on the footwall (Fig. 5). This estimate is much greater than that documented in the Chichi earthquake, and must be the result of several paleoearthquakes. The timing and offset of these past events can be deduced from observed stratigraphic onlaps, progressive fault displacements on the stratigraphic units, and fault intersections and terminations. In previous excavations along the Chelungpu fault (Fig. 1), three paleoearthquake events have been recognized during the intervals of 300-430 cal yr B.P. (event E1), 710-800 cal yr B.P. (event E2), and 17101900 cal yr B.P. (event E5) (W. S. Chen et al., 2001a, b, 2004, 2006; Ota et al., 2001, 2006; A. R. Streig et al., unpublished manuscript, 2006). In the following section, we discuss the paleoearthquake events that are recognizable at the Chushan site, and attempt to correlate the surface-rupture events with these previous events.

In previous studies, we documented the stratigraphic record of deformation that was associated with fault-propagation folding from the Chichi earthquake rupture (W. S. Chen et al., 2004, 2006). Trenches at the Siangong temple and Shijia sites show the existence of onlap features and unconformities at the fold scarp that indicate surface coseismic deformation. These sedimentological features result from scarp growth after a displacement event at the leading edge of the thrust fault, followed by alluvial and colluvial depositions that unconformably onlap the scarp (e.g., Atwater et al., 1990; Carver and McCalpin, 1996; Weaver and Dolan, 2000). At the Chushan trench, we observed similar onlapping features and unconformities which suggest three possible events (E3, E4, and E5). Event E3 occurred at the top of the B1 layer, event E4 at the top of the B2 layer, and event E5 at the top of the B4 layer (Figs. 3, 4, and 9a,b). We now discuss the sedimentary evidence for each of the three events.

\section{Event E2}

On the north wall of the Chushan site the deformation that was caused by the penultimate event produced a folded sequence which developed on the lower unit $\mathrm{A}$ above a thrust that now shows a ramp-flat feature (green line, Fig. 9b). The vertical displacement of the B1 layer across 
the fold is $0.6 \mathrm{~m}$ (Figs. $9 \mathrm{~b}$ and $10 \mathrm{~b}$ ), and the horizontal displacement of the B4 layer across the fault is $2.5 \mathrm{~m}$. The surface deformation from this event is expressed as a faultpropagation fold that is characterized by an asymmetric anticline that involves the lower unit A and unit B. The penultimate event also appears to have produced a wedgeshaped open fissure that is filled with gravel from the top of lower unit A. The fold appears to be overlain by gravel beds from upper unit $\mathrm{A}$ that were undisturbed by the folding (Figs. 4 and 9b). Hence, the penultimate event on the fault occurred after the deposition of lower unit A and before that of upper unit A. On the south wall, no clear fold can be observed in lower unit A, but numerous shear planes occur there (green lines, Fig. 9a). The determination of faulting succession using structural features is usually not easy but the excavation revealed an interesting feature; the weathered mottle structure truncates and disturbs the shear planes that represent a paleoearthquake event before the Chichi earthquake (W. S. Chen et al., 2004). Based on radiocarbon ages from lower unit A of 680-980 cal yr B.P. and upper unit A of 540-670 cal yr B.P. (Fig. 8), the penultimate event is likely to have occurred between $540 \mathrm{cal} \mathrm{yr} \mathrm{B.P.} \mathrm{and} 980 \mathrm{cal}$ yr B.P. Because the open fissure formed at the top of lower unit A, the penultimate event is likely to have occurred after most of lower unit A had been deposited, which suggests that the event may have occurred near 680-790 cal yr B.P. (Fig. 8). Based on this estimate, the penultimate event correlates to event E2 (710-800 cal yr B.P.), which has been identified at the Pineapple field and Shijia sites (W. S. Chen et al., 2004, 2006).

\section{Event E3}

On the north wall of the Chushan trench, an alluvial gravel bed within unit A pinches against the B1 layer at the fold scarp (Figs. 5 and 9b). In addition, the lower unit A is deposited on the footwall and onlaps the fold scarp below the forelimb. Event E3 was responsible for the onlap relations between lower unit A and the overlying B1 layer. We also identified event E3 on the south wall of the trench, where a block of unit $\mathrm{C}$ was deposited on the scarp above the B1 layer and subsequently buried by lower unit A (Figs. 3 and 9a). Further evidence of a deformation event just before the deposition of lower unit $\mathrm{A}$ is the presence of a significant influx of charcoal detritus. The ages of this detritus suggests that lower unit $\mathrm{A}$ is composed of reworked unit B material (B2 and B3 layers) (Fig. 8). This relationship is probably the result of a deformation event that produced scarp growth and the subsequent erosion of unit B. On the south wall, the deformation produced a main thrust with a ramp feature. The vertical displacement responsible for unit $\mathrm{D}$ on both sides of the main fault is $1.1 \mathrm{~m}$ high, and may have been a product of event E3 (Fig. 10c).

At 910-980 cal yr B.P. (Zs148), the age of lower unit $\mathrm{A}$ is the upper chronological limit for event E3, and at $710-950$ cal yr B.P., the age of the top of the B1 layer is the lower chronological limit. This brackets the event between $710 \mathrm{cal}$ yr B.P. and $950 \mathrm{cal}$ yr B.P., a range that has not been recognized at other trench sites along the Chelungpu fault.

\section{Event E4}

This event is recognizable by the onlap of the B1 layer over the B3 layer on the south wall of the trench (Figs. 3 and 9a). This has no similar relationship on the north wall, possibly because of hanging-wall erosion. The B2 layer occurs as an eastward-thinning wedge that onlaps onto the B3 layer on both walls. These onlap relations potentially define a paleoearthquake event, but there is not enough evidence to allow us to define an additional earthquake event between the B2 and B3 layers. Based on the radiocarbon dates, the B2 and B3 layers were deposited during the same period (Fig. 8). In addition, the convoluted layer, sand dike, and crack-filling features that occur within the B2 and B3 layers probably represent earthquake-induced liquefaction (Figs. 3 and 4). Although we cannot locate the source of the earthquake that induced the liquefied features, this observation and the stratigraphic constraint suggest that the Chelungpu fault activity probably occurred later than the deposition of the B2 layer and earlier than the deposition of the B1 layer.

Deposits at the base of the B1 layer give a radiocarbon age of 1380-1550 cal yr B.P. (Zs135), and the B2 layer gives a radiocarbon age range of $1540-1810 \mathrm{cal}$ yr B.P. Hence, event E4 occurred after $1540-1810 \mathrm{cal}$ yr B.P. and near to 1380-1550 cal yr B.P. (Fig. 8). Although it is less well defined than event E3, event E4 has not been observed at other locations. Moreover, the vertical displacement of the event cannot be estimated because the B1 layer is not present in the hanging wall.

\section{Event E5}

This event is defined based on the observation that the B3 layer unconformably onlaps the B4 layer in both trench walls (Figs. 3, 4, and 9a, b). Event E5 was responsible for the onlap relations between the B4 and B3 layers. The lower chronological limit of $1740-1930 \mathrm{cal}$ yr B.P. is constrained by the top of the B4 layer on the south wall (Zs128) (Fig. 8). The upper chronological limit is constrained by the mixed age of the B3 layer from eight radiocarbon dates (Fig. 8). Event E5 occurred before 1530-1710 cal yr B.P. and after 1740-1930 cal yr B.P. Using these age constrains, event E5 may correlate to events that have already been recognized at these sites, including an event at 1710-1930 cal yr B.P. that has been documented at the Pineapple field site (W. S. Chen et al., 2004), an event with a lower limit age of 1810 $1960 \mathrm{cal}$ yr B.P. that has been documented at the Siangong temple site (W. S. Chen et al., 2006) and an event that occurred at 1700-2000 cal yr B.P. at the Fengyuan site (Ota et al., 2005, 2006). The vertical offset of event E5 also cannot be estimated. The well logging and trench investigation of unit $\mathrm{G}$ on both sides of the main thrust reveal a total 
vertical offset of $7 \mathrm{~m}$ (Fig. 7). The vertical offset of the last four events, including the Chichi earthquake, is $3.4 \mathrm{~m}$. Hence, we estimate that the total vertical offset from events $\mathrm{E} 4$ and E5 is estimated at $3.6 \mathrm{~m}$ high, and their average vertical offset is $1.8 \mathrm{~m}$.

From our stratigraphic interpretation of deformed and onlap features, five surface-rupturing earthquake events, including the Chichi earthquake, can be recognized at the Chushan site. Unfortunately, with the exceptions of the Chichi earthquake and events E2 and E3, the only evidence of these earthquake events comes from sedimentary features. There is no additional evidence that would allow us to determine the displacement of events E4 and E5. Moreover, we did not observe any coarse-grained wedge deposits on the footwall that could have been used to identify a paleoearthquake event. Previous studies at the Siangong temple and Shijia sites identified coseismic growth folding and sedimentation above a blind thrust. Several sedimentary features that were observed in the Holocene deposits showed wedge-shaped deposits, unconformities, and onlap structures. Each onlap structure and wedge-shaped deposit was inferred to have been produced by a paleoearthquake event (W. S. Chen et al., 2006; A. R. Streig et al., unpublished manuscript, 2006). Hence, we can consider the onlap features of the Chushan site as being of highly reliable for inferring earthquake events. These colluvial wedges are usually composed of coarse-grained gravel within a sandy matrix that is shed onto a footwall, such as unit A at this site and the Pineapple field site (W. S. Chen et al., 2004). However, the Shijia site showed that these colluvial wedges are mainly composed of fine-grained sand and silt due to events E1 and E2, because the exposed strata on the hanging wall is overlaid with finegrained deposits (W. S. Chen et al., 2006). At the Chushan site, the deposits on the hanging wall are still overlaid with fine-grained deposits from units F, E, D, and C (Figs. 2-4). This indicates that unit $\mathrm{B}$ is probably a fine-grained colluvium that was reworked from units E, D, C, and part of unit B.

Units F, E, D, and C on both sides of the fold-axis show the same sedimentary facies, thickness, and lithologic characters. The results from these sedimentary features allow us to speculate that the fold was formed after the deposition of unit $\mathrm{C}$. This could have been the result of a coseismic fold that occurred after the deposition of unit $\mathrm{C}$ and before the deposition of the B1 layer. However, as the deformation shows a monoclinal fold, we cannot determine the coseismic events through the intersecting relationships between the structure and stratigraphy. Nevertheless, unit B was probably deposited below the pre-existing fold scarp, with its deposits aggregated upward onto the scarp of the forelimb of the monoclinal fold. The onlap relationship between the deposition of unit $\mathrm{C}$ and the $\mathrm{B} 1$ layer was caused by coseismic deformation during event $\mathrm{E} 5$. Based on the onlap relation of unit $\mathrm{B}$, the sedimentation rate reveals less than the relative uplift rate, and the top of the structure may be eroded, resulting in an unconformity. Because we could not find a clearly eroded contact on the forelimb strata, we can only speculate that the unconformity was eroded afterward during the deformation.

The dips of onlap layers at the forelimb increase from $34^{\circ}$ at the top of lower unit A to $82^{\circ}$ (overturn) at the B4 layer on the south wall and from $15^{\circ}$ to $58^{\circ}$ (overturn) on the north wall (Fig. 9a, b). The upward change of the bed dips and onlap structures (unconformity) within the forelimb indicates that the monoclinal fold grew by repeated deformation (Atwater et al., 1990; Schneider et al., 1996; Edward et al., 1997; Poblet et al., 1998; Chen et al., 2006). The timing of the fold growth is bracketed by the age of the sediment layer, as in layers B3, B2-B1, and in lower unit A. Deformation began after the deposition of the top of the underlayer and was terminated before the deposition of the overlying layer. By discriminating the onlap structure, we are confident that the discordant strata occurred due to movement on the faulting of the rollover anticline. The E3, E4, and E5 events can probably be identified, although it is possible that the pattern of strata onlap could have been generated by repeated fluvial deposits from flooding. However, even when we discount the overall deformation for the last three paleoearthquake events, the deformation still remains a 3.6-m-high fold scarp (Fig. 10d). The deformation must have occurred after the deposition of unit $\mathrm{C}$. Of all the events we are only unable to confirm event E4, which was formed by either a fault-driven or fluvial-driven event. But, regarding the larger amount of deformation, a better explanation needs to go through events twice. Hence, we consider that it is a coseismic fault-driven event.

\section{Discussion and Conclusions}

A comparison of the previous paleoseismic data indicates that most of the trenches contain evidence of the penultimate event between $300 \mathrm{cal}$ yr B.P. and $430 \mathrm{cal}$ yr B.P. However, we could not identify that event at the Chushan site (Fig. 11), probably because it was too small to reveal surface ruptures (Ran et al., 2003; W. S. Chen et al., 2004). The surface rupturing during individual earthquakes actually occurred in a wider zone that was probably several tens to hundreds of meters farther from the main fault (W. S. Chen et al., 2001a, b, 2004). Previous work clearly identified the penultimate event (E1) at the Mingjian site about $4.3 \mathrm{~km}$ north of the Chushan site, where the Chichi earthquake rupture formed about $45 \mathrm{~m}$ apart from the E1 event (W. S. Chen et al., 2001a). Before the earthquake, the Chushan site formed a gentle slope along the frontal foothills without any significant geomorphic expressions such as a linear scarp. The topographic map presents a well developed and continuous 3-m-high terrace scarp to the west of this site (Fig. 2). The Chichi earthquake rupture occurred north of that scarp and followed an eastward direction close to the trench site along the boundary between the foothills and the terrace. This indicates that the scarp is probably the result of the Chelungpu fault. In addition, unit $\mathrm{G}$, between the fault tip and borehole $\mathrm{A}$ on the hanging wall, has about $10 \mathrm{~m}$ of 


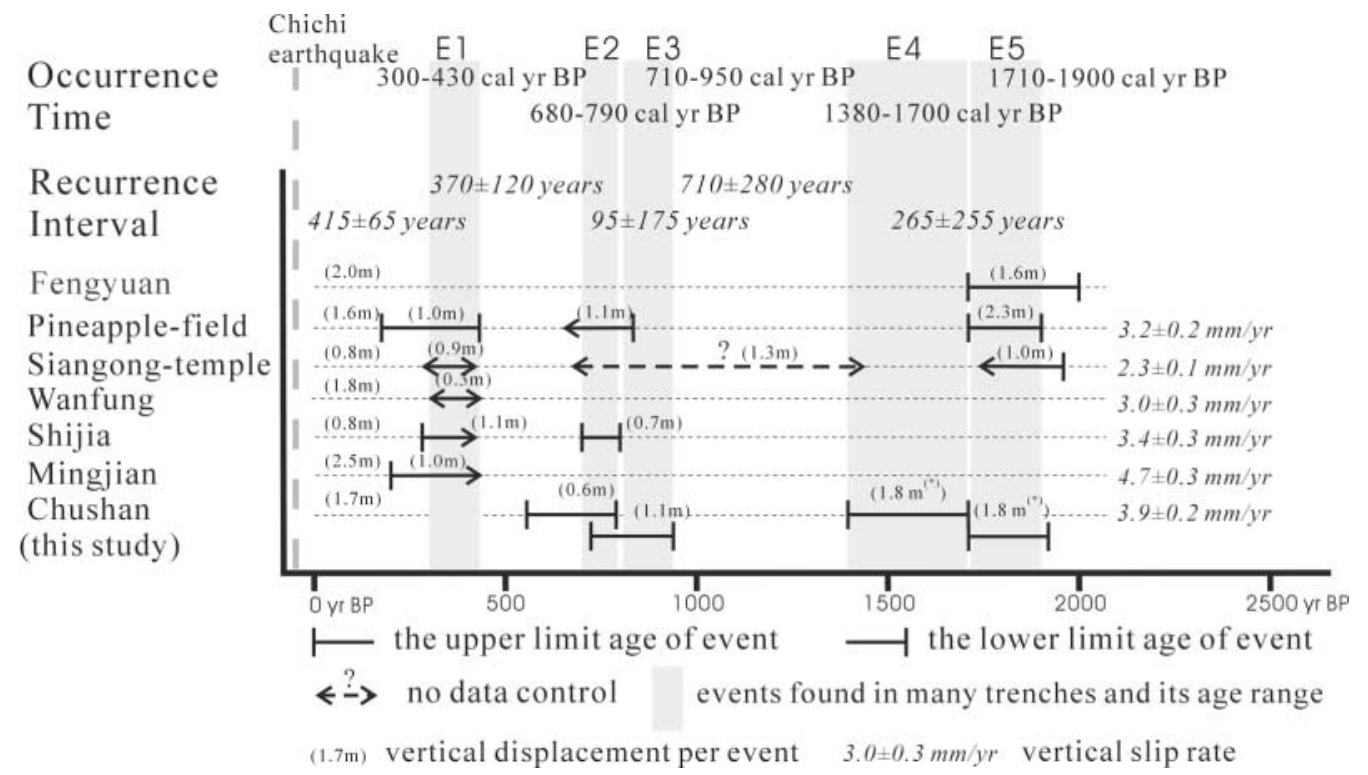

Figure 11. The seismological history of the Chelungpu fault is combined with six other trench studies. The dashed gray line indicates the Chichi earthquake in 1999 A.D. The black bars are the age ranges of the paleoearthquake events at individual trench sites. The occurrence time estimate corresponds to the shaded area which is correlated to paleoearthquake events among the seven trenches. (*) The code of events E4 and E5 is reported as the averaged displacement of the two events because of poorly defined vertical displacement.

vertical separation (Fig. 7). The Pliocene basement within borehole A contains intensively sheared planes. Even though the penultimate event was not exposed in the trench site, we cannot rule out the possibility that it did occur on the hanging wall or along the scarp.

Based on structural and geologic features, most of the trench sites are located along the same segment of the Chelungpu fault, with the exception of the Fengyuan site (Fig. 1). The fault behavior obtained from these trenches should be very similar; although the Chushan site contains a record of two new events, E3 and E4, which were not reported in earlier works. Events E3 and E4 have 1.1-m and 1.8-m vertical offsets, respectively, which seems to be similar to or larger than the single displacement for other events. The average vertical offsets of E1, E2, and E5 are $0.88 \mathrm{~m}$, $1.03 \mathrm{~m}$, and $1.63 \mathrm{~m}$, respectively (Fig. 11). Events E1 and E2 occurred along the Chelungpu fault, which is $45 \mathrm{~km}$ in length, and event E5 occurred along the Shihkang and Chelungpu faults, which are $86 \mathrm{~km}$ in length (Fig. 1). Although the relationship between displacement and rupture length is less well correlated, Wells and Coppersmith (1994) statistically analyzed 55 earthquake ruptures to evaluate the relationship for all slip types and devised an equation. Testing that equation on the displacements of events E3 and E4 produces an estimated surface rupture of at least $100 \mathrm{~km}$ in length. Based on displacement and fault segmentation from the geologic features, we suggest that the two events could both have occurred along the Chelungpu fault, although the exact relationship is uncertain.

\section{Recurrence Time and Interval}

Based on the radiocarbon age constraints of the paleoearthquakes, the Chushan site shows five events clustered at 540-790 cal yr B.P. (E2), 710-950 cal yr B.P. (E3), 13801700 cal yr B.P. (E4), 1710-1930 cal yr B.P. (E5), and the 1999 Chichi earthquakes (Fig. 8). By combining the results from six previous trench studies, we can infer that the seismological record of the Chelungpu fault contains six surfacerupturing earthquakes that occurred in 1999 A.D., 300430 cal yr B.P., 680-790 cal yr B.P., 710-950 cal yr B.P., 1380-1700 cal yr B.P., and 1710-1930 cal yr B.P. (Fig. 11). The measured average recurrence interval for the Chichi earthquake through event E5 allows us to conclude that there were relatively short recurrence intervals of $415 \pm 65,370$ $\pm 120,95 \pm 175,710 \pm 280$, and $265 \pm 255$ years. These recurrence intervals are not uniform, except for the last two (Chichi earthquake/E1 and E1/E2), which are well constrained by chronological dates in three of the trenches. The intervals in the past 2 ka have a maximum of about 700 years and a minimum of about 100 years.

\section{Slip Rates}

To estimate the slip rate, we measured the slip orientation, fault dip, and vertical displacement in the excavated exposures. However, we identified no striations on the fault plane to quantify the slip direction of the fault. In previous studies, we only obtained slip directions on the Chichi earthquake rupture, and these were directly measured from slick- 
ensides within the bedrock or from disrupted artificial features, such as city streets, embankments, bridges, riverbanks, fences, or dams. Such slip indicators reveal pure thrusting $\left(\mathrm{N} 70-90^{\circ} \mathrm{W}\right)$ on the Chelungpu fault. Hence, we can use the slip orientation of the Chichi earthquake rupture, and the vertical displacement in the trench, to estimate the short-term slip rate. However, our paleoseismic studies may have been excavated across single splays within broad rupture zones, so that incomplete paleoearthquake sequences may be documented. For example, we may have missed event E1 in the Chushan trench, or it may not have extended that far south. Consequently, the estimated vertical slip rates only provide a minimum rate. Based on the vertical displacement, fault plane dips, and the occurrence age of the older event (E5), we estimate the vertical slip rate at the Chushan trench to be at least $3.9 \pm 0.2 \mathrm{~mm} / \mathrm{yr}$. As no striations were observed on the fault plane in the trench to quantify the slip rate of the fault, we use the vertical slip rate via the fault dip to estimate a slip rate of $9.6 \pm 0.5 \mathrm{~mm} / \mathrm{yr}$. The vertical rate estimated through the paleoseismological analysis of the previous studies ranges from $2.3 \pm 0.1 \mathrm{~mm} / \mathrm{yr}$ to $4.7 \pm 0.3 \mathrm{~mm} / \mathrm{yr}$ (Fig. 11). The long-term vertical slip rate found in geomorphological studies can be calculated using measured vertical offset and the dating of the late Pleistocene and Holocene river terraces on the hanging wall. The long-term vertical slip rate of the Chelungpu fault has been estimated as 2.8$5.0 \mathrm{~mm} / \mathrm{yr}$ in the past $67 \mathrm{ka}$ (Y. G. Chen et al., 2003). A comparison between long- and short-term vertical slip rates shows similar values.

\section{Acknowledgments}

The paleoseismic studies were supported by the National Science Council (NSC 91-2119-M-002-022) and the Central Geological Survey (92EC2A380204).

\section{References}

Atwater, B. F., D. A. Trumm, J. C. Tinsley, R. S. Stein III, A. B. Tucker, D. J. Donahue, A. J. T. Jull, and L. A. Payen (1990). Alluvial plains and earthquake recurrence at the Coalinga anticline, in The Coalinga, California, Earthquake of May 2, 1983, M. J. Rymer and W. L. Ellsworth (Editors), U.S. Geol. Surv. Profess. Pap. 1487, 273-298.

Carver, G. A., and J. P. McCalpin (1996). Paleoseismology of compressional tectonic environments, in Paleoseismology, J. P. McCalpin (Editor), International Geophysics Series, Vol. 62, Academic Press, San Diego, 183-270.

Chang, H. C. (Editor) (1999). Geologic report of the 1999 Chi-Chi earthquake, Taiwan, Central Geological Survey, 315 pp. (in Chinese).

Chen, W. S., Y. G. Chen, and H. C. Chang (2001a). Paleoseismic study of the Chelungpu fault in the Mingjian area, West. Pacific Earth Sci. 1, no. 3, 351-358.

Chen, W. S., Y. G. Chen, H. C. Chang, Y. H. Lee, and C. C. Lee (2001b). Paleoseismic study of the Chelungpu fault in the Wanfung area, West. Pacific Earth Sci. 1, no. 4, 43-72.

Chen, W. S., Y. G. Chen, R. C. Shih, T. K. Liu, N. W. Huang, C. C. Lin, S. H. Sung, and K. J. Lee (2003). A modern analog of the out-ofsequence thrust system in relation with the Chi-Chi earthquake ruptures in the Western Foothills, central Taiwan, J. Asian Earth Sci. 21, 473-480.
Chen, W. S., B. S. Huang, Y. G. Chen, Y. H. Lee, C. N. Yang, C. H. Lo, H. C. Chang, Q. C. Sung, N. W. Huang, C. C. Lin, S. H. Sung, and K. J. Lee (2001c). Chi-Chi earthquake, 1999 September 21: a case study on the role of thrust-ramp structures for generating earthquakes, Bull. Seism. Soc. Am. 91, no. 5, 986-994.

Chen, W. S., K. J. Lee, L. S. Lee, D. J. Ponti, C. Prentice, Y. G. Chen, H. C. Chang, and Y. H. Lee (2004). Slip rate and recurrence interval of the Chelungpu fault during the past 1900 years, Quat. Int. 115116, 167-176.

Chen, W. S., K. J. Lee, L. S. Lee, A. R. Streig, H. C. Chang, and C. W. Lin (2006). Paleoseismic evidence for coseismic growth-fold in the 1999 Chichi earthquake and earlier earthquakes, central Taiwan, $J$. Asian Earth Sci. (in press).

Chen, Y. G., W. S. Chen, J. C. Lee, Y. H. Lee, C. T. Lee, H. C. Chang, and C. H. Lo (2001). Surface rupture of 1999 Chi-Chi earthquake yields insights on active tectonics of central Taiwan, Bull. Seism. Soc. Am. 91, no. 5, 977-985.

Chen, Y. G., W. S. Chen, Y. Wang, P. W. Lo, J. C. Lee, and T. K. Liu (2002). Geomorphic evidence for prior earthquakes: Lesson from the 1999 Chichi earthquake in central Taiwan, Geology 30, no. 2, 171-174.

Chen, Y. G., Y. W. Chen, W. S. Chen, J. F. Zhang, H. Zhao, L. P. Zhou, and S. H. Li (2003). Preliminary results of long-term slip rates of 1999 earthquake fault by luminescence and radiocarbon dating, Quat. Sci. Rev. 22, no. 10-13, 1213-1221.

Edward, M. F., A. Williams, and A. Artoni (1997). Progressive evolution of a fault-related fold pair from growth strata geometries, Sant Llorenc, de Morunys, SE Pyrenees, J. Struct. Geol. 19, no. 3-4, 413-441.

Erslev, E. A. (1991). Trishear fault-propagation folding, Geology 19, $617-$ 620.

Hsieh, U. S., and M. B. Tsai (1985). Historical Earthquake Catalogues in China, Beijing Press, 1-4.

Kelson, K. I., K. H. Kang, W. D. Page, C. T. Lee, and L. S. Cluff (2001). Representative styles of deformation along the Chelungpu fault from the 1999 Chi-Chi (Taiwan) earthquake: geomorphic characteristics and responses of man-made structures, Bull. Seism. Soc. Am. 91, no. 5, 930-952.

Lee, J. C., Y. G. Chen, K. Sieh, K. Muller, W. S. Chen, H. T. Chu, Y. C. Chan, C. Rubin, and R. Yeats (2001). A vertical exposure of the 1999 surface rupture of the Chelungpu fault at Wufeng, western Taiwan: structural and paleoseismic implications for an active thrust fault, Bull. Seism. Soc. Am. 91, no. 5, 914-929.

Obermeier, S. F., and E. C. Pond (1999). Issues in using liquefaction features for paleoseismic analysis, Seism. Res. Lett. 70, 34-58.

Ota, Y., Y. G. Chen, and W. S. Chen (2005). Review on paleoseismological and active fault studies in Taiwan in the light of the Chichi earthquake of September 21, 1999, Tectonophysics 408, 63-77.

Ota, Y., C. Y. Huang, P. B. Yuan, Y. Sugiyama, Y. H. Lee, M. Watanabe, H. Sawa, M. Yanagida, S. Sasake, and K. Tanifuchi (2001). Trenching study at the Tsaotun site in the central part of the Chelungpu Fault, Taiwan, West. Pacific Earth Sci. 1, no. 4, 487-498.

Ota, Y., M. Shishikura, M. Watanabe, H. Sawa, M. Yamaguchi, M. Yanagida, K. Ichikawa, Y. H. S. T. Lee, Lu, T. S. Shih, and S. Amagasa (2006). Paleoseismology deduced from the Fengyuan trench on the northern part of the Chelungpu fault central Taiwan-an example of very low angle reverse fault, J. Asian Earth Sci. (in press).

Poblet, J. J., A. Munoz, and A. Trave (1998). Quantifying the kinematics of detachment folds using three-dimensional geometry: application to the Mediano anticline (Pyrenees, Spain), Geol. Soc. Am. Bull. 110, no. $1,111-125$.

Ran, Y. K., P. Z. Zhang, and L. C. Chen (2003). Late Quaternary history of paleoseismic activity along the Hohhot segment of the Daqingshan piedmont fault in Hetao depression zone, North China, Ann. Geophys. 46, no. 5, 1053-1069.

Schneider, C. L., C. Hummon, R. S. Yeats, and G. L. Huftile (1996). Structural evolution of the northern Los Angeles basin, California, based on growth strata, Tectonics 15, no. 2, 341-355.

Shin, T. C., K. W. Kuo, W. H. K. Lee, T. L. Teng, and Y. B. Tsai (2000). 
A preliminary report on the 1999 Chi-Chi (Taiwan) earthquake, Seism. Res. Lett. 71, 24-30.

Storti, F., F. Salvini, and K. McClay (1997). Fault-related folding in sandbox analogue models for thrust wedges, J. Struct. Geol. 19, no. 3-4, 583-602.

Sung, Q. C., Y. C. Chen, H. Tsai, Y. G. Chen, and W. S. Chen (2000). Comparison study on the coseismic deformation of the 1999 Chi-Chi earthquake and long-term stream gradient changes along the Chelungpu fault in central Taiwan, Terr. Atmos. Oceanic Sci. 11, 735-750.

Weaver, K. D., and J. F. Dolan (2000). Paleoseismology and geomorphology of the Raymond fault, Los Angeles County, California, Bull. Seism. Soc. Am. 90, no. 6, 1409-1429.

Wells, D. L., and K. J. Coppersmith (1994). New empirical relationships among magnitude, rupture length, rupture width, rupture area, and surface displacement, Bull. Seism. Soc. Am. 84, no. 4, 974-1002.
Department of Geosciences

National Taiwan University

Taipei 106, Taiwan, Republic of China

(W.-S.C., C.-C.C., Y.-C.Y., L.-S.L., K.-J.L., H.-C.Y)

Central Geological Survey

Taipei 235, Taiwan, Republic of China

(H.-C.C., C.-W.L., W.-H.L., T.-S.S., S.-T.L.)

Yokohama National University

79-1 Tokiwadai, Hodogaya-ku

Yokohama 240-8501, Japan

(Y.O.)

Manuscript received 28 July 2005. 